\title{
Science Learning Motivation in Rural Schools
}

Law Hui Haw*, Sabariah Bte Sharif, Crispina Gregory K Han

Universiti Malaysia Sabah, Kota Kinabalu, Sabah, Malaysia

DOI: $10.36347 /$ sjahss.2021.v09i05.007

| Received: 13.04.2020 | Accepted: 22.05.2021 | Published: 23.05.2021

*Corresponding author: Law Hui Haw

Abstract

Original Research Article

Motivation has been identified as a great factor influencing the effectiveness of the teaching and learning process. This study aimed to look at the level of science learning motivation of students in rural secondary schools. The study was administered using a questionnaire on 237 Grade 11 students of a rural secondary schools who took general science subject. The data obtained were analyzed using Statistical Package for the Social Science Version 21.0 (SPSS 21.0) software. Mean scores and t-test were used to find out the level of student motivation and gender differences towards science learning. Findings show that both groups of male and female students have a high level of motivation to learn science. The learning foal orientation scale showed the highest mean value of 3.97 while the self -efficacy scale had the lowest mean score value of 3.57. The findings also show that there are significant differences between genders for the level of science learning motivation. Besides, the finding also showed that there is a strong and positive relation between science learning motivation and science achievement.

Keywords: Motivation, Science learning motivation, science achievement, rural schools.

Copyright () 2021 The Author(s): This is an open-access article distributed under the terms of the Creative Commons Attribution 4.0 International License (CC BY-NC 4.0) which permits unrestricted use, distribution, and reproduction in any medium for non-commercial use provided the original author and source are credited.

\section{INTRODUCTION}

Motivation plays an important role in student engagement toward achieving goals [1, 2]. Brown [3] defines motivation as the guidance, impulses and internal emotions or desires that drive an action. In the context of education, motivation is all the means of initiating and maintaining learning behaviors, prerequisites or co-conditions for meaningful learning to occur [4]. According to Lin [5], two different areas outlined in motivation are intrinsic motivation, which focuses on achievement from performing activities and extrinsic motivation is innate satisfaction from performing activities.

Achievement Goal Theory is one of the theories that are often used in the social cognitive framework to explain learning motivation and behavior. Achievement goal theory is based on two concepts of competence, namely mastery goals and performance goals. Dweck and Leggett [2] alerted researchers from error and concluded that both concepts of ability in influencing an individual's overall knowledge. In contrast, the construction of achievement goal theory is used to explain how individuals with similar intelligence acquire different levels of success and failure in facing challenges. The learning process uses goal orientation as an important catalyst in the learning process [6].
Previous studies have demonstrated the importance of learning motivation factors on academic achievement [7-9]. In the studies of students 'science learning motivation, researchers have examined why students strive to learn science, how they work intensively, and what attitudes, feelings, and emotions characterize them in the process. Britner and Pajares [10] state that student motivation in science learning is one of the most important predictors of science subject success. Most students who are motivated to learn science reported not only because thinks science is useful in later careers, but also because they find it relevant to health, life and their understanding of the world [11]. There are findings that report that students with lower levels of motivation in science have lower performance as well [12]. Hanrahan [13] also stated that an important key in successful science learning is positive motivation. Therefore, it is important to know the level of motivation of students, especially in learning science.

Malaysia is still experiencing a sharp decline in the assessment of benchmarks namely Trends in International Mathematics and Science Study (TIMSS) and the Program for International Student Assessment (PISA) respectively. For example, the average score for science has dropped drastically from 510 in 2003 to 471 in 2007 and the result fell further to 426 in 2011 [14]. 
Law Hui Haw et al., Sch J Arts Humanit Soc Sci, May, 2021; 9(5): 188-193

The average score has risen back to 426 in TIMSS in 2015. However, the results are still below the Intermediate bench marking of 475. The score for Malaysian science achievement is 471 compared to the international average score of 486. This means that on average our science achievement level is 15 points away from the average score it should be. Thus, the achievement of Science in TIMSS can be said to reach only low benchmarks.

Besides, there is also a gap in academic achievement between states in Malaysia. From the national test, Malaysian Certificate of Education, Sarawak state has ranked among the last in the country compared to other states [15]. Sarawak is one of the states which have the most rural schools. In addition, there is an issue of lower achievement in the rural schools [16-18]. Since learning motivation is agreed as an important factor in science education $[19,20]$ then this study will try to identify the level of science learning motivation in rural schools in Sarawak, Malaysia. The research questions for this study are:

1. What is the level of science learning motivation of rural secondary school students?

2. Is there any significant difference in the level of science learning motivation of rural secondary school students according to gender?

3. What is the relationship between the science learning motivation and science achievement in rural secondary school students?

Moreover, the hypothesis tested in this study is:

$\mathrm{H}_{0} 1$ : There is no significant difference in the level of science learning motivation of rural secondary school students according to gender

$\mathrm{H}_{0} 1_{\mathrm{a}}$ : There is no significant difference in the level of learning goal orientation of rural secondary school students according to gender

$\mathrm{H}_{0} 1_{\mathrm{b}}$ : There is no significant difference in the level of task value of rural secondary school students according to gender

$\mathrm{H}_{0} 1_{\mathrm{c}}$ : There is no significant difference in the level of self-efficacy of rural secondary school students according to gender
$\mathrm{H}_{0} 2$ : There is no relationship between the science learning motivation and science achievement in rural secondary school students

$\mathrm{H}_{0} 2_{\mathrm{a}}$ : There is no relationship between the learning goal orientation and science achievement in rural secondary school students

$\mathrm{H}_{0} 2_{\mathrm{b}}$ : There is no relationship between the task value and science achievement in rural secondary school students

$\mathrm{H}_{0} 2_{\mathrm{c}}$ : There is no relationship between the self-efficacy and science achievement in rural secondary school students

\section{METHODOLOGY}

This is a descriptive study and aims to determine the level of student motivation in learning science subjects. This study uses a quantitative survey method, by conducting the questionnaire on the students involved as a sample.

The researchers conducted this study on Grade 11 students in a rural district in Sarawak, Malaysia. The study population consisted of all senior secondary form students (Grade 10 and 11) in the district while the study sample consisted of 237 students, who were selected by simple random sampling. According to Azizi et al. [21], such sampling methods produce high confidence in population conditions. Based on the rule of thumb proposed by Zikmund [22], the number of samples should be not less than 30 and not more than 500 for most studies.

The instrument used were translated and adapted from 'Students Adaptive Learning Engagement in Science (SALES)' by Velayutham et al. [23]. The actual questionnaire consisted of 24 items covering 3 dimensions. The key dimensions in this instrument are learning goal orientation, task value and self -efficacy. The respondent responded by using the 5 point of Likert scale; 1 = never, 2 =sometimes, $3=$ not sure, $4=$ always, 5 = very always.

Table-1: Summary of tests

\begin{tabular}{|c|l|l|}
\hline & Research Questions & Tests \\
\hline 1 & What is the level of science learning motivation of rural secondary school students? & $\begin{array}{l}\text { Statistic } \\
\text { Descriptive }\end{array}$ \\
\hline 2 & $\begin{array}{l}\text { Is there any significant difference in the level of science learning motivation of rural } \\
\text { secondary school students according to gender? }\end{array}$ & t-test \\
\hline 3 & $\begin{array}{l}\text { What is the relationship between the science learning motivation and science achievement } \\
\text { in rural secondary school students? }\end{array}$ & $\begin{array}{l}\text { Pearson } \\
\text { Correlation }\end{array}$ \\
\hline
\end{tabular}

\section{FINDINGS}

Table 2 shows the analysis of mean and standard deviation for all respondents. The findings of the study showed that rural students had a high level of motivation for learning science according to a mean score of 3.78. With a standard deviation of 0.41 . Found the mean score obtained from 237 respondents, the scale with the highest mean score is the learning goal orientation scale of $3.97(79.40 \%)$, followed by the task value with a mean score of $3.79(75.80 \%)$ while the self 
Law Hui Haw et al., Sch J Arts Humanit Soc Sci, May, 2021; 9(5): 188-193

-efficacy scale has a mean score of the lowest of 3.57

with an agreement percentage of $71.40 \%$.

Table-2: Level of science learning motivation and scales

\begin{tabular}{|l|l|l|l|}
\hline & Mean & Percentage (\%) & Standard Deviation \\
\hline Science Learning Motivation & 3.78 & 75.60 & 0.41 \\
\hline Learning Goal Orientation & 3.97 & 79.40 & 0.51 \\
\hline Task Value & 3.79 & 75.80 & 0.45 \\
\hline Self-efficacy & 3.57 & 71.40 & 0.50 \\
\hline
\end{tabular}

From Table 3, the motivation in science learning for girls generally is higher, with a mean score of 3.88 than boys who only scored 3.65 on average. Besides, based on the scales of motivation, the mean score obtained from the girls are all higher than the boys. In learning goal orientation, the girls showed a mean score of 4.10 , followed by the task value of 3.88 and self-efficacy of 3.66. Meanwhile, the boys showed the mean score of 3.82, 3.68 and 3.45 for learning goal orientation, task value and self-efficacy respectively. Overall, the level of science learning motivation for girls is high but only moderate in boys according to Sahandri et al. [24].

Table-3: Science Learning Motivation According To Gender

\begin{tabular}{|l|l|l|l|}
\hline & Gender & Mean & Standard Deviation \\
\hline Science Learning Motivation & Boys & 3.65 & 0.04 \\
\cline { 2 - 4 } & Girls & 3.88 & 0.03 \\
\hline Learning Goal Orientation & Boys & 3.82 & 0.05 \\
\hline & Girls & 4.10 & 0.04 \\
\hline Task Value & Boys & 3.68 & 0.04 \\
\hline & Girls & 3.88 & 0.04 \\
\hline Self-efficacy & Boys & 3.45 & 0.05 \\
\hline & Girls & 3.66 & 0.04 \\
\hline
\end{tabular}

Based on the Levene's Test, the sig value = 0.417 , which is $>0.05$. This means that the variance of both groups of male and female students is the same. Given the sig value. (2-tailed) were 0.000 and $<0.05$, then the null hypothesis (there was no significant difference in the level of science learning motivation of rural secondary school students by gender) was rejected. The same things go to learning goal orientation, task value and self-efficacy. The analyses showed that there was significant difference in all the scales in science learning motivation by gender. Thus, all the Hypothesis null 2 are rejected. The analyses of independent t-test are as Table 4 below.

Table-4: Results of T-Test

\begin{tabular}{|c|c|c|c|c|c|}
\hline & \multicolumn{2}{|c|}{ Levene's Test for Equality of Variances } & \multicolumn{2}{|c|}{ t-test for Equality of Means } \\
\hline & & $\mathrm{F}$ & Sig & $\mathrm{t}$ & Sig. (2-tailed) \\
\hline \multirow[t]{2}{*}{ Motivation } & Equal variances assumed & 0.662 & 0.417 & -4.37 & 0.000 \\
\hline & Equal variances not assumed & & & -4.33 & 0.000 \\
\hline \multirow[t]{2}{*}{ LG } & Equal variances assumed & 0.602 & 0.439 & -4.26 & 0.000 \\
\hline & Equal variances not assumed & & & -4.21 & 0.000 \\
\hline \multirow[t]{2}{*}{ TV } & Equal variances assumed & 1.694 & 0.194 & -3.48 & 0.001 \\
\hline & Equal variances not assumed & & & -3.44 & 0.001 \\
\hline \multirow[t]{2}{*}{$\mathrm{SE}$} & Equal variances assumed & 0.190 & 0.889 & -3.50 & 0.001 \\
\hline & Equal variances not assumed & & & -3.36 & 0.001 \\
\hline
\end{tabular}

Thereafter, Pearson correlation coefficients were calculated to find out the relationships between motivation in science learning and science achievement. Results in Table 5 show positive and significant correlations between the motivation in science learning with achievement with the coefficient of 0.506 . The value is between $0.50-1.00$, hence science learning motivation correlates positively and strongly with science achievement [25]. Even though the Pearson coefficient of learning goal orientation is 0.463 and task value is 0.455 , which is $<0.5$, but is considered to have a positive and moderate relationship with science achievement [26]. Last but not the least, the selfefficacy had a coefficient value with 0.384 , which shows a positive and weak relationship with science achievement. Thus, all the hypothesis null 3 are rejected. 
Table-5: Correlation between science learning motivations with science achievement

\begin{tabular}{|l|l|l|l|l|l|}
\hline & & Motivation & Learning Goal Orientation & Task Value & Self Efficacy \\
\hline $\begin{array}{l}\text { Science } \\
\text { Achievement }\end{array}$ & $\begin{array}{l}\text { Pearson } \\
\text { Correlation }\end{array}$ & 0.506 & 0.463 & 0.455 & 0.384 \\
\hline & Sig. (2-tailed) & .000 & .000 & .000 & .000 \\
\hline
\end{tabular}

The summary of the analysis based on the hypotheses are as Table 6.

Table-6: Summary of analysis

\begin{tabular}{|l|l|l|l|}
\hline & Hypothesis & Findings \\
\hline $\mathrm{H}_{0} 1:$ & $\begin{array}{l}\text { There is no significant difference in the level of science learning motivation of rural secondary } \\
\text { school students according to gender }\end{array}$ & Rejected \\
\hline & $\mathrm{H}_{0} 1_{\mathrm{a}}:$ & $\begin{array}{l}\text { There is no significant difference in the level of learning goal orientation of rural } \\
\text { secondary school students according to gender }\end{array}$ & Rejected \\
\hline $\mathrm{H}_{0} 1_{\mathrm{b}}:$ & $\begin{array}{l}\text { There is no significant difference in the level of task value of rural secondary school } \\
\text { students according to gender }\end{array}$ & Rejected \\
\hline $\mathrm{H}_{0} 2:$ & $\begin{array}{l}\text { There is no relationship between the science learning motivation and science achievement in } \\
\text { rural secondary school students }\end{array}$ & $\begin{array}{l}\text { There is no significant difference in the level of self-efficacy of rural secondary school } \\
\text { students according to gender }\end{array}$ & Rejected \\
\hline & $\begin{array}{l}\mathrm{H}_{0} 2_{\mathrm{a}}: \\
\text { There is no relationship between the learning goal orientation and science achievement } \\
\text { in rural secondary school students }\end{array}$ & Rejected \\
\hline $\mathrm{H}_{0} 2_{\mathrm{b}}:$ & $\begin{array}{l}\text { There is no relationship between the task value and science achievement in rural } \\
\text { secondary school students }\end{array}$ & Rejected \\
\hline $\mathrm{H}_{0} 2_{\mathrm{c}}:$ & $\begin{array}{l}\text { There is no relationship between the self-efficacy and science achievement in rural } \\
\text { secondary school students }\end{array}$ & Rejected \\
\hline
\end{tabular}

\section{DISCUSSIONS}

The results show that the level of motivation to learn science subject for rural secondary school students in Sarawak is high. The finding is slightly different from the previous research such as Chan and Norlizah [27] and Chow and Yong [28] which showed the level of motivation is only moderate in learning science. However, the result is in line with a study showing that students have a high level of science learning motivation by LIbao et al. [29] in the Philippines. The learning goal orientation and task value scale showed a high level while the self-efficacy scale showed only moderate level. Thus, the findings give a clearer picture on the motivation in science learning. The students in rural areas are found to be lack of confidence in learning science. Since the self-efficacy is also very important influences academic achievement, and appears as a strong predictor of self-regulation [30] then self-efficacy or self confidence in science learning should be improved.

In terms of gender, the level of motivation of female students was found to be higher than male students. These findings are in line with the study of Chumbley et al. [31] and Cavas [20]. One similarity gained from male and female students was that each of them had only a moderate level of self-efficacy. According to Urdan and Schoenfelder [32], differences in motivation levels are not only due to individual differences but are influenced by the learning environment. Therefore, educators need to change the variables that can be manipulated such as teaching strategies, physical or social environment in the classroom in increasing the level of student learning motivation.

Furthermore, the study supports the ideas of Patrick et al. [33] and Tuan et al. [34]. that the motivation in learning science has a significant relation with the achievement of science. The finding is different from Sevinç et al. [35], who reported that the performance goal correlates the least with science achievement. The finding showed that the learning goal orientation has the highest correlation with science achievement. Besides, the result is not consistent as Schunk [36] and Tuan et al. [34] showed that selfefficacy has the highest correlation with student achievement in science. Anyway, the current study shows that the science learning motivation with the science achievement is significantly correlated in the context of rural schools.

\section{CONCLUSION}

Learning motivation is an important predictor in determining academic success. Thus, it is desirable for educators to know the level of motivation for science learning. From the findings of the study, the level of science learning motivation of students in rural schools in Sarawak is high. However, students were found to have only a moderate level of self-efficacy. The findings also show that there is a significant difference between the levels of science learning motivation of male students with female students. In addition, the science learning motivation correlates 
Law Hui Haw et al., Sch J Arts Humanit Soc Sci, May, 2021; 9(5): 188-193

positively and strongly with science achievement. These findings have may lead the educators to understand better the situation of science learning motivation, especially in the rural schools. The alternatives can be taken to improve the difference of motivational level between genders and keep maintaining a good motivation level.

\section{REFERENCES}

1. Ames, C. (1992). Classrooms: Goals, structures, and student motivation. Journal of educational psychology, 84(3), 261.

2. Dweck, C. S., \& Leggett, E. L. (1988). A socialcognitive approach to motivation and personality. Psychological review, 95(2), 256.

3. Brown, H. D. (2000). Principles of language learning and teaching (Vol. 4). New York: Longman.

4. Palmer, D. H. (2009). Student interest generated during an inquiry skills lesson. Journal of Research in Science Teaching: The Official Journal of the National Association for Research in Science Teaching, 46(2), 147-165.

5. Lin, H. F. (2007). Effects of extrinsic and intrinsic motivation on employee knowledge sharing intentions. Journal of information science, 33(2), 135-149.

6. Umbarger, A. L. (2015). Achievement goal orientations, cognitive learning strategy use, and continued professional learning plans of first-year occupational therapy assistant students (Doctoral dissertation, University of Toledo).

7. Elliot, A. J., McGregor, H. A., \& Gable, S. (1999). Achievement goals, study strategies, and exam performance: A mediational analysis. Journal of educational psychology, 91(3), 549.

8. Hustinx, L., Handy, F., Cnaan, R. A., Brudney, J. L., Pessi, A. B., \& Yamauchi, N. (2010). Social and cultural origins of motivations to volunteer: A comparison of university students in six countries. International sociology, 25(3), 349-382.

9. McKenzie, K., \& Schweitzer, R. (2001). Who succeeds at university? Factors predicting academic performance in first year Australian university students. Higher education research \& development, 20(1), 21-33.

10. Britner, S. L., \& Pajares, F. (2006). Sources of science self- efficacy beliefs of middle school students. Journal of Research in Science Teaching: The Official Journal of the National Association for Research in Science Teaching, 43(5), 485-499.

11. Glynn, S. M., Taasoobshirazi, G., \& Brickman, P. (2007). Nonscience majors learning science: A theoretical model of motivation. Journal of Research in Science Teaching: The Official Journal of the National Association for Research in Science Teaching, 44(8), 1088-1107.

12. Glynn, S. M., Taasoobshirazi, G., \& Brickman, P. (2009). Science motivation questionnaire:
Construct validation with nonscience majors. Journal of Research in Science Teaching: The Official Journal of the National Association for Research in Science Teaching, 46(2), 127-146.

13. Hanrahan, M. U. (2002). Learning science: Revisiting humanist dimensions of intellectual engagement. Australasian Science Education Research Association.

14. Ministry of Education Malaysia. (2012). Preliminary Report of the Malaysia Education Development Plan 2013-2025. Putrajaya: Ministry of Education Malaysia.

15. Ministry of Education Malaysia. (2013). Malaysia Education Blueprint 2013-2025. Putrajaya: Ministry of Education Malaysia.

16. Ministry of Education Malaysia. (2018). Annual Report. Putrajaya: Ministry of Education Malaysia.

17. Ijenkeli, O. E., Paul, A. I., \& Vershima, A. M. (2012). Impact of career-related instruction on mathematics achievement of rural and urban students in Benue state, Nigeria. Research Journal of Mathematics and Statistics, 4(2), 39-41.

18. Chianson, M. M. (2012). School location as a correlate of mathematics students achievement in a cooperative learning class. Journal of Education and Leadership Development, 4, 42-46.

19. Glynn, S. M., \& Koballa, T. R. (2006). Motivation to learn in college science. Handbook of college science teaching, 25, V32.

20. Cavas, P. (2011). Factors affecting the motivation of Turkish primary students for science learning. Science education international, 22(1), 31-42.

21. Azizi, Y., Fawziah, Y., Zurihanmi, Z., dan, N. Y. (2005). Pembangunan Kendiri. Skudai: Penerbit Universiti Teknologi Malaysia.

22. Zikmund, W. G., Babin, B. J., Carr, J. C., \& Griffin, M. (2010). Business research methods (8th ed.). Mason, HO: Cengage Learning.

23. Velayutham, S. (2012). The Influence of Classroom Environment on Students' Motivation and SelfRegulation. Unpublished Doctoral Dissertation. Curtin University, Australia.

24. Hamzah, M. S. G. B., Saad, N. S., Abdullah, S. K., Muhammad, M. M., \& Nasri, H. Z. K. (2014). Transformation of Research Instrument Development in Education. US-China Education Review, 679.

25. Lay, Y. F., Khoo, C. H., \& Ley, C. M. (2016). Pengenalan Kepada Analisis Data Dengan IBM SPSS STATISTICS 19 Dalam Penyelidikan Sains Sosial. Kota Kinabalu: Penerbit Universiti Malaysia Sabah.

26. Hussin, F., Ali, J., \& Noor, M. S. Z. (2014). Kaedah penyelidikan \& analisis data SPSS. Universiti Utara Malaysia Press.

27. Chan, Y. L., \& Norlizah, C. H. (2017). Students' motivation towards science learning and students' science achievement. International Journal of 
Academic Research in Progressive Education and Development, 6(4), 2226-6348.

28. Chow, S. J., \& Yong, B. C. S. (2013). Secondary school students' motivation and achievement in combined science. Online Submission, 3(4), 213228.

29. LIbao, N. J. P., Sagun, J. J. B., Tamangan, E. A., Pattalitan Jr, A. P., Dupa, M. E. D., \& Bautista, R. G. (2016). Science Learning Motivation as Correlate of Students' Academic Performances. Journal of Technology and Science Education, 6(3), 209-218.

30. Pintrich, P. R., \& Zeidner, M. (2000). Handbook of self-regulation. Elsevier Science \& Technology.

31. Chumbley, S. B., Haynes, J. C., \& Stofer, K. A. (2015). A Measure of Students' Motivation to Learn Science through Agricultural STEM Emphasis. Journal of Agricultural Education, 56(4), 107-122.

32. Urdan, T., \& Schoenfelder, E. (2006). Classroom effects on student motivation: Goal structures, social relationships, and competence beliefs. Journal of school psychology, 44(5), 331349.
33. Patrick, H., Mantzicopoulos, P., \& Samarapungavan, A. (2009). Motivation for learning science in kindergarten: Is there a gender gap and does integrated inquiry and literacy instruction make a difference. Journal of Research in Science Teaching: The Official Journal of the National Association for Research in Science Teaching, 46(2), 166-191.

34. Tuan*, H. L., Chin, C. C., \& Shieh, S. H. (2005). The development of a questionnaire to measure students' motivation towards science learning. International journal of science education, 27(6), 639-654. Tuan*, H. L., Chin, C. C., \& Shieh, S. H. (2005). The development of a questionnaire to measure students' motivation towards science learning. International journal of science education, 27(6), 639-654.

35. Sevinc, B., Ozmen, H., \& Yigit, N. (2011). Investigation of Primary Students' Motivation Levels towards Science Learning. Science Education International, 22(3), 218-232.

36. Schunk, D. H. (1991). Self-efficacy and academic motivation. Educational Psychologists, 26, 207232. 